\title{
DISTURBANCE HISTORY OF A MIXED CONIFER STAND IN CENTRAL IDAHO, USA
}

\author{
KAREN B. ARABAS ${ }^{1 *}$, BRYAN BLACK ${ }^{2}$, LEIGH LENTILE ${ }^{3}$, JIM SPEER $^{4}$, and JODI SPARKS 5 \\ ${ }^{1}$ Department of Environmental and Earth Sciences, Willamette University, 900 State Street, Salem, Oregon 97301, USA \\ ${ }^{2}$ Hatfield Marine Science Center, Oregon State University, 2030 SE Marine Science Drive, Newport, OR 97365, USA \\ ${ }^{3}$ Dept. of Forestry and Geology, University of the South, 735 University Ave., Sewanee, TN 37383, USA \\ ${ }^{4}$ Dept. of Environmental and Ecological Sciences, Indiana State University, 159 Science Building, Terre Haute, IN 47809, \\ USA \\ ${ }^{5}$ Dept. of Geography, Geology, and Anthropology, Indiana State University, 159 Science Building, Terre Haute, IN 47809, \\ USA
}

\begin{abstract}
We apply a combination of suppression and release criteria to reconstruct the disturbance history of a ponderosa pine - Douglas-fir stand in central Idaho. In this stand, disturbance, likely fire, induced growth releases in some trees, and sudden, severe suppressions in others. To characterize growth release following disturbance, we developed boundary-line release criteria for Douglas-fir and ponderosa pine. Suppression criteria were applied to identify disturbances defined as a growth reduction of more than 1.8 standard deviations sustained for a minimum of five years. To prevent confusing a true release event with growth increases associated with recovery from suppression, release events were not tallied for at least fifteen years following a suppression event. Release and suppression events were combined to create a disturbance chronology characterized by a high frequency of disturbance between 1820 and 1920. This period of disturbance likely reflects post-European settlement land uses such as grazing and logging as well as an increase in fire frequency. Fire suppression in the latter part of the $20^{\text {th }}$ Century likely explains the decrease in disturbance after 1940 . We believe that a combination of release as well as suppression criteria best describes the disturbance history of this stand.
\end{abstract}

Keywords: Boundary line, tree ring, release criteria, suppression criteria, disturbance history.

\section{INTRODUCTION}

Dendroecological methods are widely used to establish long-term patterns in forest change including successional trends (Henry and Swan 1974; Abrams et al. 1995), the nature, intensity, and frequency of disturbance events (Swetnam et al. 1985; Foster 1988; Swetnam and Betancourt 1990; Veblen et al. 1991a), and the effects of human influences on ecosystem processes (Savage 1991). A fundamental dendroecological procedure for quantifying forest disturbance histories is the identification of release events in time series of radial growth increment measurements (Lorimer

*Corresponding author: karabas@willamette.edu; Fax 503-370-6773; Telephone 503-370-6666 and Frelich 1989; Black and Abrams 2003). Although release criteria capture major, standwide disturbances, they also have proven particularly useful and unique in their ability to detect minor disturbance events such as the formation of forest canopy gaps. To date, most studies involving release criteria have been conducted in the closed-canopy, temperate forests of eastern North America where trees readily show the effects of changes in competition (Hough and Forbes 1943; Payette et al. 1990; Nowacki and Abrams 1997). Comparatively few studies have applied release criteria in the more arid regions of western North America where stand densities are low and trees may not show strong competitive signals (but see: Kienast and Schweingruber 1986; Veblen 1986; 
Veblen et al. 1989). Although disturbance histories for relatively arid sites are typically reconstructed from fire scars and age-structure data, release criteria may provide valuable information for relatively mesic sites where tree density and competition are high enough to limit growth.

To investigate the applicability of release criteria in western forests, we develop a disturbance history for a mesic, mixed-conifer stand in central Idaho. Release criteria are developed following the boundary-line technique (or prior growth technique) first described for eastern hemlock (Tsuga canadensis L.) by Black and Abrams (2003). This approach attempts to standardize release criteria within and among species to allow for comparisons of disturbance histories among sites. Most release criteria are calculated using the change in relative growth rate over time within each measurement time series. A pulse in relative growth rate that exceeds a set threshold is counted as a release event (Rubino and McCarthy 2004). The increase in relative growth rate a tree experiences for a given level of crown release, however, varies among species and among size, age, and crown classes within a species (Lorimer and Frelich 1989; Orwig and Abrams 1994; Nowacki and Abrams 1997; Ruffner and Abrams 1998). A single threshold will underestimate the possible release response of entire species, or of crown, size, or age classes within a species. Boundary-line release criteria are based on the observation that prior growth (average ring width over the previous ten years) better predicts the increase in relative growth rate following a disturbance than crown, age, or size class (Black and Abrams 2003). Within a species, each pulse in relative growth rate is scaled to the maximum possible value predicted by prior growth, standardizing all releases across various stages of the tree's life history, and presumably yielding a more accurate disturbance history.

Although less frequently employed, suppression criteria have also proven useful for identifying disturbance events, particularly those that cause significant damage to surviving trees. For example, the sudden and pronounced suppressions following defoliation are often an integral part of reconstructing insect outbreak events (Swetnam et al. 1985; Veblen et al. 1991b; Speer et al. 2001; Davis et al. 2007). Suppression criteria have also been applied to identify the frequency of canopydamaging storm events in the forests of the eastern United States (Orwig et al. 2001; Lafon and Speer 2002), and root-damaging earthquakes along the San Andreas Fault (Jacoby et al. 1988). In these situations, release often represents a growth rebound that occurs several years after the damage has occurred. Thus, the release is lagged and does not accurately reflect the timing of the disturbance. Sometimes trees react differently to canopy disturbance, with some trees showing releases while others undergo suppression or develop reaction wood or reduced latewood (Sheppard et al. 2005). Given the possibility of damaging events at our study site, particularly from fire, we investigate the suitability of suppression criteria in combination with release criteria to develop a disturbance history for the site. To increase the accuracy of our disturbance history, we include other indicators of disturbance such as fire scars and traumatic resin rings. The objectives of this study are to i) apply boundary-line release criteria to ponderosa pine (Pinus ponderosa Dougl. ex P. \&. C. Laws.) and Douglas-fir (Pseudotsuga menziesii (Mirabel) Franco), ii) investigate suppression events in both species and any interactions with release events, iii) date fire scars in ponderosa pine and traumatic resin rings in Douglas-fir as additional indicators of disturbance, iv) integrate releases, suppressions, fire scars, and traumatic resin rings to generate a disturbance history for the site, and v) interpret the final chronology in the context of land-use history.

\section{STUDY AREA}

The study site is located in the Meadow Marsh compartment ( $\sim 6.5$ ha) of Ponderosa State Park in west-central Idaho, a relatively mesic site in the dry mixed-conifer forests of the region. Ponderosa State Park is located on the north end of a peninsula intruding Big Payette Lake near the University of Idaho McCall Field Campus. Study sites were located in UTM Zone 11, 0572534 Northing 4975755 Easting, and at elevation $\sim 1535 \mathrm{~m}$. (Figure 1). Local bedrock consists of 


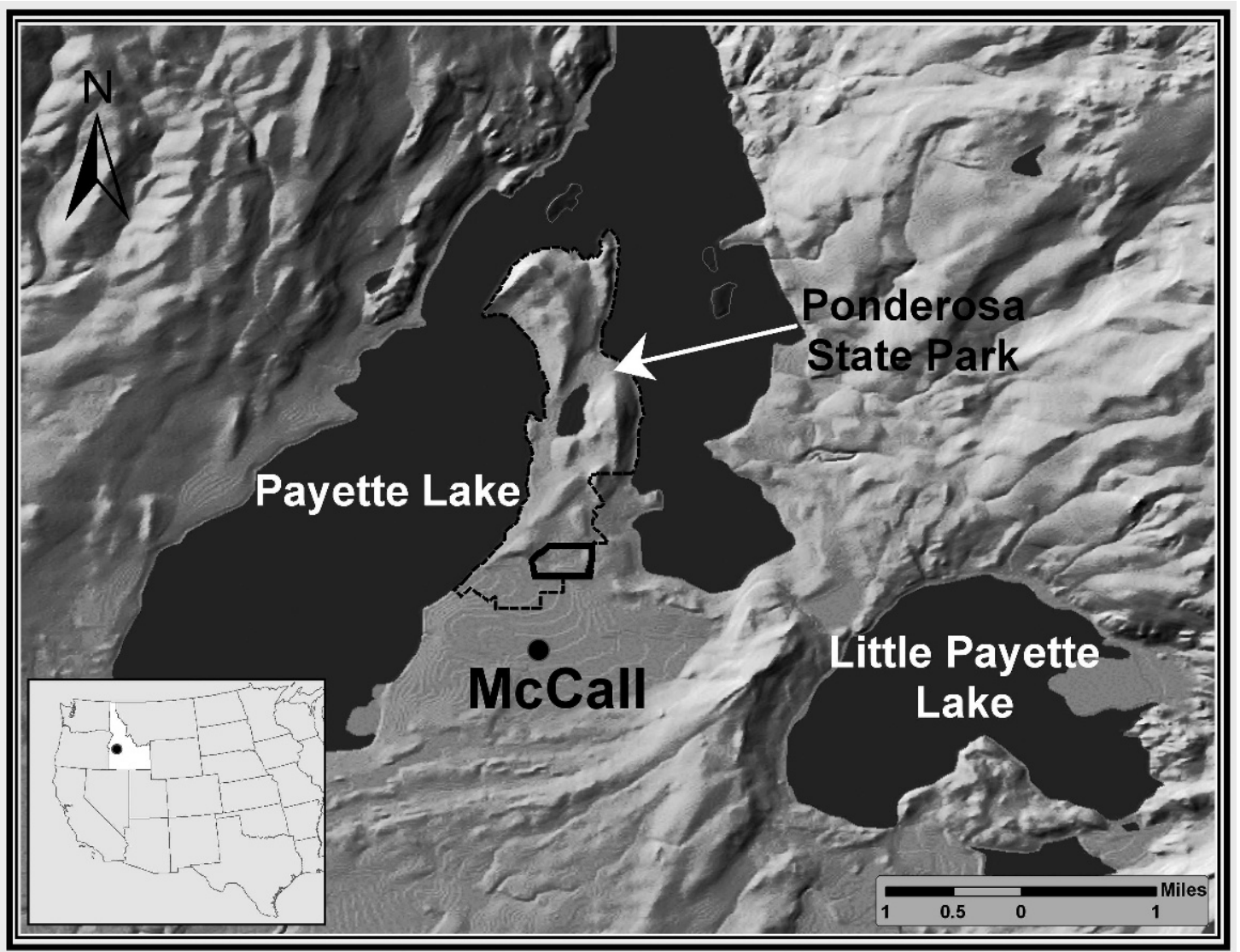

Figure 1. Map of the study area in south central Idaho. The black polygon on the southeastern edge of Ponderosa State Park is the Meadow Marsh compartment where the data were collected.

granitic, Cretaceous Idaho batholith, with some Columbia River basalts around the margins of the lake (Colman and Pierce 1986). Soils are deep, well drained, relatively infertile, poorly developed inceptisols that formed in glacial till on glacial moraines (USDA-NRCS 1981, 2007). Although winter climate is influenced by moist Pacific air masses, the climate is largely continental with hot and dry summers (Taplin and Peckham 1994). The nearby town of McCall receives $\sim 700 \mathrm{~mm}$ of precipitation annually, and annual snow accumulation can be heavy $(>3500 \mathrm{~mm})$ (NOAA-WRCC 2007). Tree species in the study area include ponderosa pine, lodgepole pine (Pinus contorta Dougl. ex Loud.), quaking aspen (Populus tremuloides Michx.), Douglas-fir, western larch (Larix occidentalis Nutt.), grand fir (Abies grandis
(Dougl.) Lind1.), and Engelmann spruce (Picea engelmannii Parry ex Engelm.). The diversity of shrubs includes huckleberry (Vaccinium spp. L.), snowberry (Symphoricarpos mollis Nutt.), and serviceberry (Amelanchier alnifolia Nutt.). Herbaceous species, including thermopsis (Thermopsis montana Nutt.), valerian (Valeriana occidentalis Heller), and sedge (Carex spp. L.), comprise the understory.

Euro-American settlers arrived in the area in the early $19^{\text {th }}$ Century, supporting themselves by hunting, mining, and later with agricultural and forestry activities. Ponderosa State Park was officially established in 1965 and is managed for recreational access, maintenance of historical character, and agency resource objectives (Taplin and Peckham 1994). 


\section{METHODS}

\section{Stand Structure and Composition}

Stand structure and composition were determined by sampling overstory and understory trees in the Meadow Marsh compartment. Ten $200 \mathrm{~m}^{2}$ circular plots were established using a stratified random sampling method along a line transect in which all stems $>4-\mathrm{cm}$ dbh (diameter at breast height) were recorded by species, diameter, and crown class (suppressed, intermediate or dominant), and from which an increment core was taken at $30 \mathrm{~cm}$ above ground level. In each of the 10 plots seedlings and saplings were counted in a $9 \mathrm{~m}^{2}$ circular subplot. Local site features, such as slope position, proximity to an edge, and evidence of rocky outcrops, were recorded. Wounds, fire scars, or other unusual features on tree boles were also noted. These plots did not contain the trees we sampled for the chronology (see below).

Increment cores were glued into core mounts, dried, and sanded using successively finer grits of sanding paper (Stokes and Smiley 1996). Ring counts were made to establish tree ages using a variable magnification binocular microscope. Where cores did not intercept the pith, the years to the pith from the innermost ring were estimated using a pith locator (sets of concentric rings that match the curvature of the innermost rings) (Applequist 1958).

\section{Chronology Development}

To generate our tree-ring chronologies, we sampled 20 of the largest (and thus oldest) Douglas-fir and 20 ponderosa pine individuals along a line transect (most of the trees were not included in the stand structure plots described above). Each tree was in the dominant crown class and was at least one crown width radius from the edge of the stand and had no external evidence of decay or severe damage. Two increment cores were collected from each tree at $30 \mathrm{~cm}$ from the ground on opposite sides of the tree (or as close to $180^{\circ}$ apart as possible). Cores were glued into core mounts, dried, and sanded using successively finer grits of sanding paper (Stokes and Smiley 1996). Skeleton plots were drawn for each core, and a master tree-ring chronology was compiled for each species. All samples were crossdated against the master chronology to ensure exact dating of each growth increment. Once visual crossdating was complete, growth increments were measured using a VELMEX tree-ring measurement system (Velmex, Bloomfield, NY) with a precision of $0.001 \mathrm{~mm}$. The International Tree-Ring Data Bank program COFECHA (Holmes 1983; Grissino-Mayer 2001) was used to verify crossdating and measurement precision. Any measurement time series with potential crossdating errors identified by COFECHA were visually checked and re-measured if necessary.

To assess stand-wide growth patterns and disturbance history, we generated a master chronology for each species. Measurement time series were detrended with either a negative exponential or negative linear regression function. Exceptions were made for any measurement time series in which the best-fit function had a positive slope. Positive slopes do not reflect age-related trends and typically occurred in trees that were suppressed from establishment until a major release event later in life. To better capture this disturbance-induced effect, series with positive-sloped, best-fit functions were detrended using the mean value of the series (a horizontal line). We chose to apply rigid functions (negative exponential or linear) to all time series to retain the maximum amount of information in both high- and lowfrequency domains. Within each species, detrended time series were averaged into a master chronology using a biweight robust mean to reduce the effects of outliers. All aspects of chronology development were performed in the International Tree-Ring Data Bank Program Library ARSTAN (Cook and Holmes 1983).

\section{Fire Scars and Resin Ring Record}

We reconstructed a local fire history by sampling fire-scarred stumps. We removed a partial or full cross-section of the stump following Arno and Sneck (1977). Stump sections were mounted onto linoleum boards, surfaced with a belt sander, and hand sanded with up to $30-\mu \mathrm{m}$ sandpaper until cellular structure was clearly visible. Each cross-section was visually crossdated 
following the procedures outlined in Stokes and Smiley (1996), using marker rings identified in the master tree-ring chronology described above. We identified annual rings containing the tip of each fire scar using a variable-magnification binocular microscope and assigned each scar a calendar year. As an additional indication of disturbance, we recorded the years in which each Douglas-fir core contained traumatic resin ducts. These "resin rings" have been shown to be associated with fire years in other species (Brown and Swetnam 1994).

\section{Boundary-Line Release Criteria}

For all measurement time series we calculated the Nowacki and Abrams (1997) running mean in which percent growth change for a year is equal to $\left(\mathrm{M}_{2}-\mathrm{M}_{1}\right) / \mathrm{M}_{1}$, where $\mathrm{M}_{1}$ equals average growth over the prior 10 years and $\mathrm{M}_{2}$ equals average growth over the subsequent 10 years. We experimented with a variety of percent-growth change thresholds $(10 \%, 25 \%, 50 \%$, etc. $)$ and found that the Nowacki and Abrams (1997) 25\% threshold did indeed screen out what appeared to be climatic signals in both ponderosa pine and Douglas-fir. For each period in which percent growth change exceeded $25 \%$, we retained the highest observed percent growth change value, calculated the maximum expected value for that year by entering the prior growth value into previously published boundary-line equations, and then divided the observed percent-growth change value by the maximum expected value (Black and Abrams 2003). All potential releases were then scaled with respect to maximum possible value as predicted by the boundary-line equation, which for ponderosa pine was $\mathrm{y}=$ $665.79 \mathrm{e}^{-0.9354 \mathrm{x}}$ and Douglas-fir was $\mathrm{y}=569.80$ $\mathrm{e}^{-0.9284 \mathrm{x}}$ (Black and Abrams 2004, 2005). All values between $25 \%$ and $50 \%$ of the boundary line were categorized as moderate releases, and all those above $50 \%$ were categorized as major releases. Furthermore, we stipulated that there could not be a true release event as detected by the Nowacki and Abrams technique for at least fifteen years following a suppression (see suppression criteria below) because such a growth increase likely reflects the tree's recovery from the suppression and not an additional disturbance event.

We also investigated the influence of climate on radial growth to ensure growth rebounds following periods of poor climate were not misidentified as true releases caused by disturbance. First, we detrended each individual series with a 50 -year cubic smoothing spline with a $50 \%$ frequency cutoff to reduce inter-tree competition signals and enhance the common climate signals in closed-canopy forests (Cook and Peters 1981). We developed a master chronology for each species by averaging the detrended time series in ARSTAN (Cook and Holmes 1983). Monthly climate data for Idaho National Climate Data Center Climate Division 4 were obtained from the National Climate Data Center (NOAA 2005) including average temperature, total precipitation, and the average Palmer Drought Severity Index (PDSI) for each month between 1895 and 2004. The master chronology of each species was correlated with monthly data using an 18-month dendroclimatic year that included six months from the prior calendar year.

To better identify the interactions between climate and disturbance signals, we removed as much climate signal as possible from the tree-ring data sets, and then performed a second iteration of release and suppression criteria. In the first step of this analysis, we averaged PDSI values for those months that were most strongly correlated with the master chronology, and performed simple linear regression between the chronology and the PDSI average. Next, we used PDSI records and the regression equation to predict the component of radial growth resulting from drought over the course of the $20^{\text {th }}$ Century. The time series of drought-related radial growth was then subtracted from each detrended measurement time series to yield a new set of time series that contained a reduced climate signal. These resulting time series were reanalyzed with suppression criteria and compared to the original outcome of our suppression analysis. Finally, we added the variance removed by detrending back into each time series in which the climate signal had been reduced, analyzed the resulting time series with release 
criteria, and compared the outcome with the original outcome of the release analysis. The variance removed by detrending had to be reintroduced before applying release criteria in order to preserve the correct prior growth values. Detrending standardized all measurement time series to a mean of one, removing all prior growth data in the process.

\section{Suppression Criteria}

We used the program OUTBREAK (Holmes and Swetnam 1996) to screen for suppression growth patterns. First, each tree-ring measurement time series was detrended using a 50-year cubic smoothing spline with a 50\% frequency cutoff. The 50-year spline removed long-term trends while preserving decadal to interannual variability, which is the timescale most relevant to detecting these suppressions. Also, with more rigid forms of detrending (i.e. negative exponential curves) we found too many false positives in our analysis. Our final criterion was that the suppression had to remain more than 1.8 standard deviations below the series mean for 5 years. All suppression events identified by OUTBREAK (Holmes and Swetnam 1996) were visually confirmed in the residual time series and in the original tree core.

\section{RESULTS}

\section{Stand Structure and Composition}

The Meadow Marsh compartment stand, though a relatively mesic site, is composed of species typical of the regional dry, mixed-conifer forests including ponderosa pine, Douglas-fir, and western larch, with Englemann spruce, lodgepole pine, grand fir, and aspen. Tree ages range from 23 to 190 years, with a median age of 83 years. As reflected by the importance value (IV-Table 1) grand fir dominates the stand. Other overstory components include Douglas-fir, ponderosa pine, and Englemann spruce (Table 1 and Figure 2). Grand fir also dominates the younger age classes, whereas ponderosa pine, Douglas-fir and Englemann spruce are the oldest trees. Grand fir is currently the only species regenerating (Figure 2).
Table 1. Forest structure and composition of sampled stands, Meadow Marsh compartment, Ponderosa State Park, Idaho. Abgr $=$ Abies grandis, Pico $=$ Pinus contorta , Pien $=$ Picea englemannii, Pipo $=$ Pinus ponderosa , Potr $=$ Populus tremuloides, Psme = Pseudotsuga menziesii Crown Class Ratios for Dominant (D), Intermediate (I), and Suppressed (S). IV $($ Importance Value $)=($ Relative Dominance + Relative Frequency + Relative Density).

\begin{tabular}{lcrcrr}
\hline Species & $\begin{array}{c}\text { Basal Area } \\
\left(\mathrm{m}^{2} / \mathrm{ha}\right)\end{array}$ & $\begin{array}{c}\text { Density } \\
\text { (\#/ha) }\end{array}$ & $\begin{array}{c}\text { Crown Class } \\
\text { Ratios (D:I:S) }\end{array}$ & $\begin{array}{c}\text { Median } \\
\text { Age (years) }\end{array}$ & IV \\
\hline Abgr & 52 & 793 & $37: 39: 43$ & 88 & 177 \\
Pico & 3 & 27 & $4: 0: 0$ & 99 & 14 \\
Pien & 10 & 53 & $5: 3: 1$ & 112 & 21 \\
Pipo & 16 & 47 & $7: 0: 0$ & 107 & 42 \\
Potr & 3 & 40 & $1: 2: 0$ & 83 & 19 \\
Psme & 2 & 60 & $2: 6: 0$ & 77 & 28 \\
AVG & & & & 91 & \\
TOTAL & 86 & 1020 & & & 300 \\
\hline
\end{tabular}

Regeneration and recruitment of all other tree species appear to have ceased $80-100$ years ago, concurrent with a pulse of grand fir regeneration.

\section{Chronology Development}

We crossdated and measured 35 ponderosa pine and 39 Douglas-fir tree cores. The total length of the ponderosa pine master series was 404 years, there were 7984 rings in the chronology, the inter-series correlation was 0.525 and the mean sensitivity was 0.249 (Supplementary Material, Table 1). The total length of the Douglas-fir master series was 327 years, there were 7233 rings in the chronology, the inter-series correlation was 0.586 and mean sensitivity was 0.208 (Supplementary Material, Table 2). Correlation coefficient matrices for both species are shown in Supplementary Tables 3 and 4 (see Supplementary Material). The oldest tree was a ponderosa pine that dated to 1602; though the establishment date is unknown as the increment core missed the pith. During crossdating, we discovered locally absent rings in samples from both species, with a maximum number of eight consecutive missing rings. In all cases, locally absent rings were associated with sudden, severe suppressions in growth that were likely induced by a damaging event such as fire. 

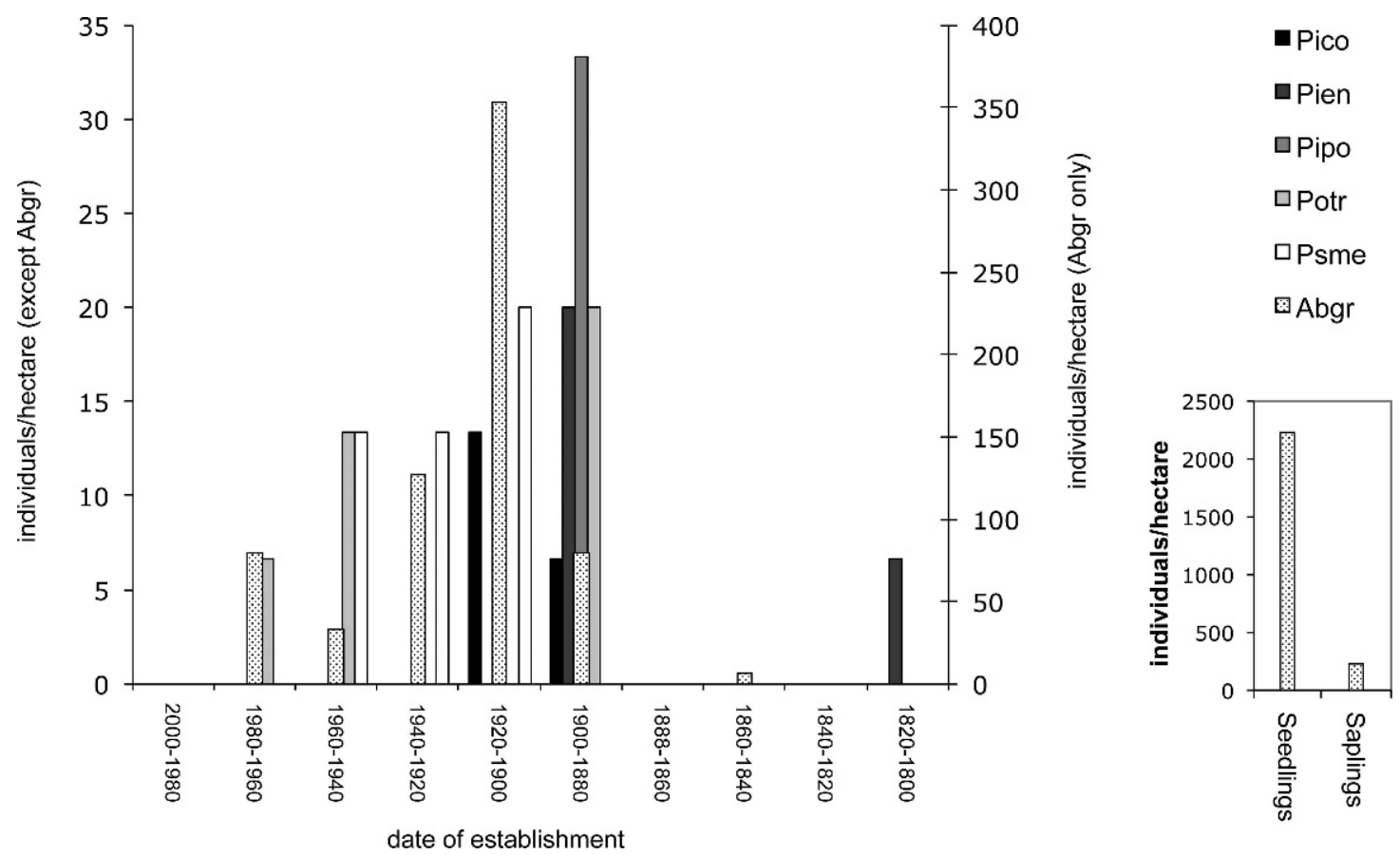

Figure 2. Forest structure at the Ponderosa State Park study site. Pico $=$ Pinus contorta, Pien $=$ Picea engelmannii, Pipo $=$ Pinus ponderosa, Potr $=$ Populus tremuloides, Psme $=$ Pseudotsuga menziesii, Abgr $=$ Abies grandis. Note the different scales on the $\mathrm{y}$-axes.

Master chronologies of both species show close synchrony in growth patterns for the duration of the chronologies (Figure 3). This is particularly true for low-frequency variability.

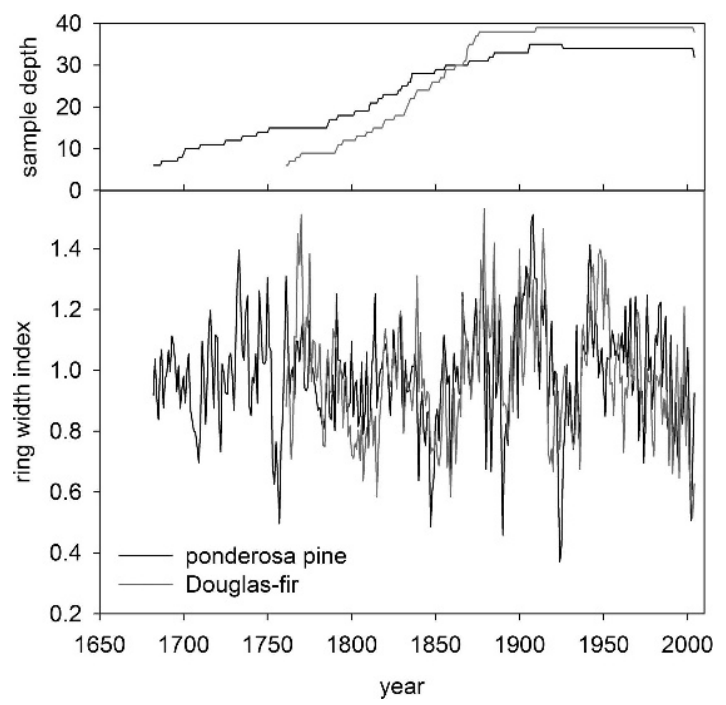

Figure 3. Master chronologies for Douglas-fir and ponderosa pine. Sample depth is greater than six as indicated in the figure.
High variance early in the chronology, especially prior to 1750 , is caused by low sample depth. Climate was found to affect growth in both species, most strongly correlated with PDSI (Supplementary Material, Table 5). PDSI is significantly and positively correlated to Douglas-fir growth every month from the previous May through the current February and the current May through the current November. The strongest correlations occur from the prior June through the prior November (ranging from $r=0.454$ to $r$ $=0.417 ; \mathrm{p}>0.001)$. Ponderosa pine growth is significantly correlated with PDSI from the previous May through the previous November and the current June through current September. Correlation is the strongest with the PDSI during the prior September $(r=0.407 ; \mathrm{p}>0.001)$. According to a regression analysis, prior September PDSI explains $15 \%$ of the variance in the ponderosa pine chronology while an average of PDSI from prior July through prior October explains $20 \%$ of the variance in the Douglas-fir chronology (Supplementary Material Table 5). The effects of long-term (multidecadal) oscilla- 

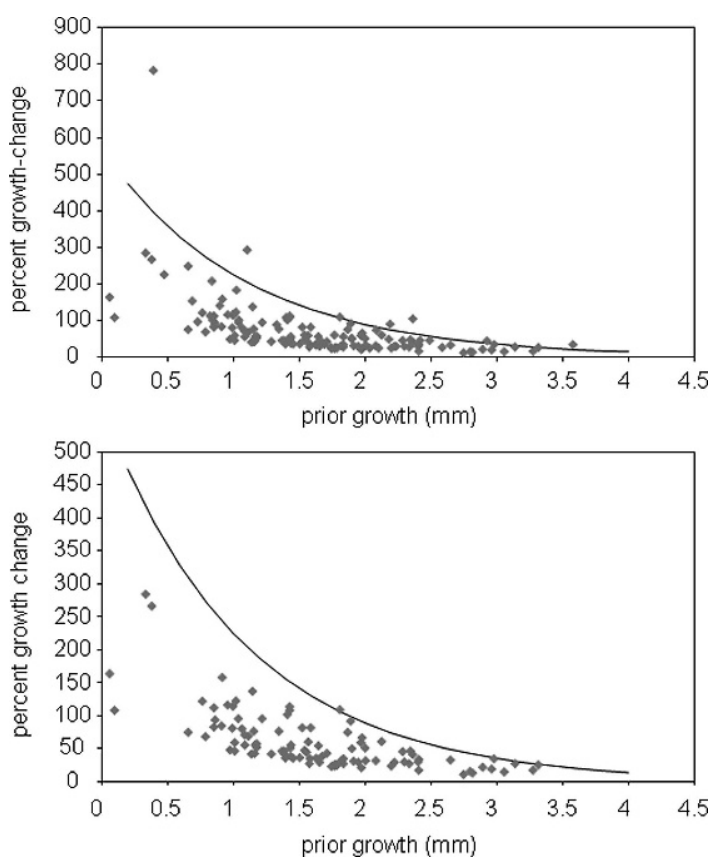

Figure 4. Top. Douglas-fir boundary line with potential releases from the Ponderosa State Park data set (including rebounds out of suppression that are not true releases). Bottom. Douglas-fir boundary line with potential releases from the Ponderosa State Park data set (excluding rebounds out of suppression that are not true releases).

tions in PDSI are clearly apparent in both chronologies throughout the twentieth century.

\section{Disturbance History}

Once outliers caused by "false releases" (growth pulses following suppressions) were removed, the boundary lines for both Douglas-fir and ponderosa pine at Ponderosa State Park are similar to those from across the ranges of both species (Figure 4). Releases and suppression events occur in both species over the past two hundred years, with differences in intensity of disturbance over time (Figure 5). Douglas-fir recorded many more release events with a mix of both major and moderate releases (20 major; 68 moderate) and somewhat fewer suppressions (85 total). Conversely, ponderosa pine recorded fewer releases (20 total; all moderate) and many more suppression events (115 total). Both species reveal a high frequency of release and suppression events between approximately 1840 and 1940. Release and suppression events are not necessarily balanced over time, suggesting various intensities or types of disturbance that favored either suppressions or releases. For example, the early 1800 s and 1920-1940 are characterized by a higher frequency of release events, whereas the decade of the 1840s, 1880-1900 and the decade of the 1910s are characterized by a predominance of suppression events (Figure 5). Removal of the PDSI signal from the tree-ring data in no way affected the final disturbance history for either species. Thus the release and suppression criteria appear to have filtered the majority of climate-related growth patterns.

A high frequency of traumatic resin rings in Douglas-fir coincides with the period of increased release/suppression frequency between 1840 and 1900 (Figure 6). Thus the onset of resin ring formation begins at approximately the same time as an increase in release and suppression events. However, elevated levels of release and suppression events persist much longer (Figure 5). Fire scars in ponderosa pine (Figure 6) are most frequent between approximately 1760 and 1890, with a large number occurring between 1840 and 1880. Fire scars occur continuously from the beginning of the chronology (1640s) and end abruptly in 1893, corresponding to the advent of fire suppression in the area.

\section{DISCUSSION}

The final disturbance chronologies track changes in the nature and intensity of disturbance in the Ponderosa State Park, Idaho. Although the exact causes of these releases and suppressions cannot be known with certainty, climate and insects are unlikely candidates. The sudden and severe growth changes are not typical of climateinduced suppressions, which tend to be more gradual or of high frequency. Removing as much climate signal as possible from the chronology made no impact on the disturbance history over the length of the climate record. Also, insects were not a likely cause of these growth patterns given that master chronologies for both ponderosa pine and Douglas-fir so closely track one another. 


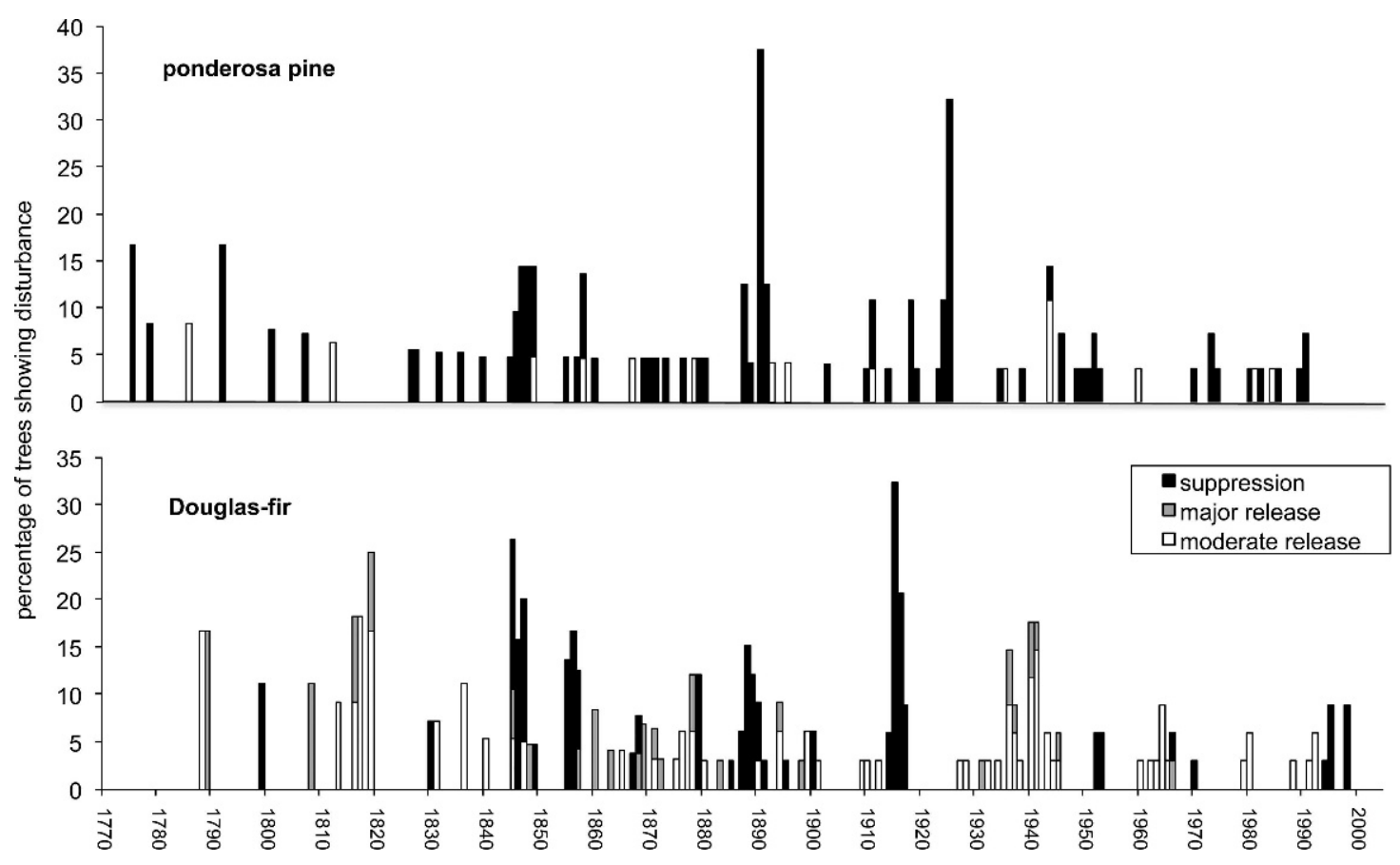

Figure 5. The percentage of measurement time series showing suppressions (events in which ring width remains more than 1.8 standard deviations below the series mean for five years), major releases (events above the $50 \%$ boundary line, threshold) and moderate releases (events between $25 \%$ and $50 \%$ of the boundary line) for ponderosa pine and Douglas-fir. Release events must occur more than 15 years following a suppression.
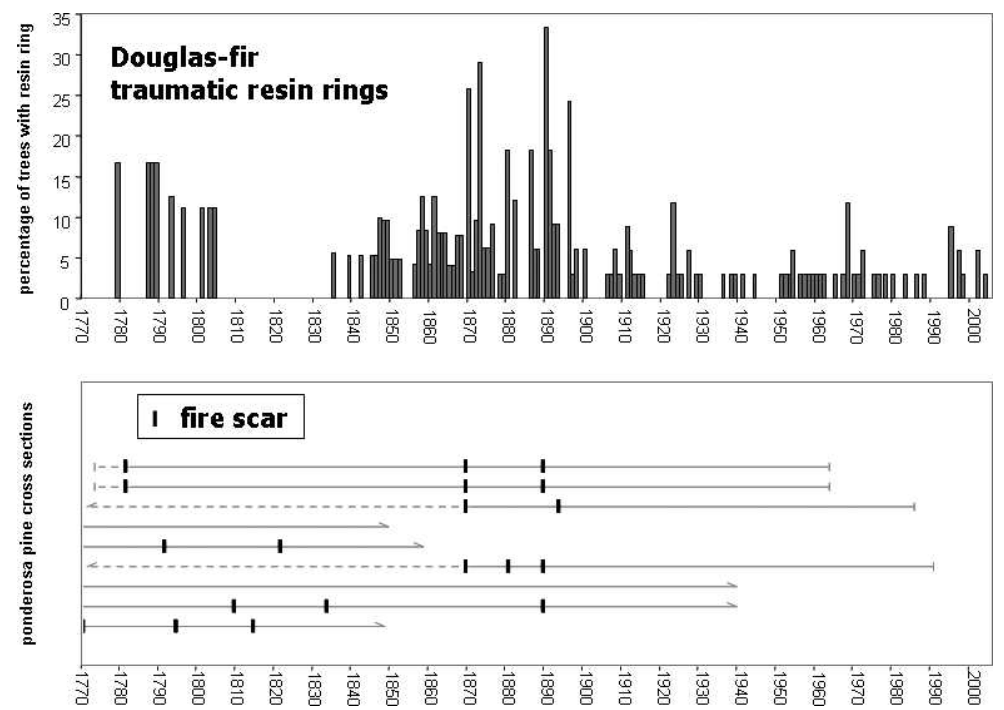

Figure 6. Percentage of Douglas-fir samples with traumatic resin rings and fire scars on ponderosa pine cross sections. 
Insects would be specific to either one of these species, causing divergences between the master chronologies. Furthermore, we did not see other signatures of insect damage such as narrow latewood in our samples. Therefore, we focus on fire, windstorms, and logging as the most likely causes of suppressions and releases.

As indicated by fire scars and charcoal found in the sediments of alluvial fans, ponderosa pine forests in the area were characterized by mixedseverity fire regimes prior to European settlement (e.g. Steele et al. 1986; Sloan 1998; Agee 1993; Pierce et al. 2004; Hessberg et al. 2005). Historical descriptions of the study area describe forests as uneven-aged and "open and park-like" with clumps of large trees and grassy understories (Crane and Fischer 1986). Although this dry mix of conifers burned frequently (5- to 30-year fire return interval) and at low intensities (Neuenschwander, unpublished), ponderosa pine forests found on more mesic sites, like the Meadow Marsh compartment, may have burned less frequently and with greater intensity (Morgan personal communication). Native tribes pre-dating European settlers were several clans of Shoshone. They were mostly nomadic because of harsh winters in the mountainous regions. When they acquired horses from southwestern tribes in the $1750 \mathrm{~s}$, trails were established that were later used by early European trappers (Craig 2002). Settlement, or at least transient use by hunters and trappers, is believed to have begun in the early to mid-1800s in the McCall area, with more permanent settlement in the late $1800 \mathrm{~s}$ (Taplin and Peckham 1994). By the 1870s grazing was common in Central Idaho (Taplin and Peckham 1994). McCall was settled in 1891, at which point timber production began with targeted harvesting of western larch and ponderosa pine as early as 1910 and continued for the next 80 years (Conley 1982; Taplin and Peckham 1994). Overall, logging and the increased fire frequency typically associated with initial settlement may explain the observed increase in disturbance in the stand. Indeed, the most severe and frequent disturbances appear to have occurred between 1840 and 1900 as reflected by peaks in the disturbance chronology, traumatic resin ring chronology, and fire scar data during that time period (Figures 5 and 6).
Disturbances continued well into the $20^{\text {th }}$ Century with the settlement of McCall. Because of the accessibility that the Northern Pacific Railroad provided, there was an influx of homes and vacation homes built in McCall beginning in 1914, activity that still continues (Conley 1982). But by all measures, disturbances in the $20^{\text {th }}$ Century appear to be less severe and frequent, particularly in comparison to the $19^{\text {th }}$ Century. Lower percentages of trees showed suppression or release, traumatic resin rings, or fire scars, particularly in the latter half of the $20^{\text {th }}$ Century (Figures 5 and 6). Fire scars noted by Ponderosa State Park personnel confirm fire frequencies of 25 years between 1840 and 1910, and no fire scars since 1910 (Taplin and Peckham 1994). Wildfire suppression in the study area began around 1920, explaining much of the reduction in disturbance indicators. The exception is the release activity in the 1940s, which is most likely a result of logging. Removal of large, overstory ponderosa pine and Douglas-fir would have accelerated succession to grand fir in disturbance-mediated succession (Abrams and Scott 1989).

Stand structure data support this interpretation (Figure 2). During the period of severe disturbances (1840-1900), the stand composition and structure began to undergo changes resulting in the current composition. Most likely as a result of fire suppression, logging, and grazing, ponderosa pine, lodgepole pine, Douglas-fir and Englemann spruce densities decreased. All but Douglasfir ceased to regenerate by the 1920 s, and Douglasfir stopped regenerating by the 1960s. As a result, grand fir expanded into the niche left by these firedependent species, dominated the stand, and it is currently the only species regenerating and being recruited into the overstory of these closed canopy stands (Figure 2). The local forest surveys conducted in 1994 reported average tree densities four times greater than historical conditions, and no successful ponderosa pine regeneration (Taplin and Peckham 1994). Other research at Ponderosa State Park notes a shift in species composition from old-growth ponderosa pine and western larch to denser stands of shade-tolerant species (Taplin and Peckham 1994; Ogle and DuMond 1997). Similar shifts in mixed-conifer forest composition and structure have been observed 
throughout the Inland Pacific Northwest (Gruell et al. 1982; Hessburg and Agee 2003; Hessburg et al. 2005), and in ponderosa pine forests throughout the western US (Covington and Moore 1994; Stephens 1998). Thus, fire exclusion has favored growth of shade-tolerant species, particularly grand fir, in forests historically dominated by ponderosa pine and western larch, ultimately altering the structure, density, composition, and function of forests in the region (Taplin and Peckham 1994). Ponderosa State Park personnel began management prescriptions to address this shift in forest composition and structure in 1994. Through a combination of understory thinning of grand fir, followed by low intensity prescribed burning, they hope to reduce competition between the overstory grand fir and the remaining dominant ponderosa pine and Douglas-fir, and to stimulate regeneration of ponderosa pine and Douglas-fir (Taplin and Peckham 1994).

Our study demonstrates the value of applying suppression criteria to compensate for disturbance signatures in tree rings that release criteria would be poorly equipped to detect. In previous instances where release criteria solely have been applied, trees have long periods of slow growth induced by competition from neighboring trees, followed by dramatically accelerated growth when neighboring trees are removed (Lorimer and Frelich 1989; Nowacki and Abrams 1997; Rentch et al. 2002). A number of years $(>5)$ may pass before the tree shows the release response, but this time period is relatively small and does not greatly contribute to error, particularly on decadal timescales. In contrast, many trees at Ponderosa State Park experienced rapid growth prior to the disturbance event, a sudden and severe suppression immediately following the disturbance event, and a growth rebound several years after the disturbance event. Suppressions often involved multiple micro- or locally absent rings, with as many as eight consecutive locally absent rings in a single suppression event indicating that the time delay before a detected release may be substantial. Ultimately, the release criteria would have detected the growth rebounds following suppression events, but the disturbance date would have been significantly underestimated. Thus, the suppression criteria improved our ability to characterize disturbance events by identifying a more precise date of the growth change associated with these disturbances, particularly ones that cause canopy damage.

We were able to identify true releases in this data set by developing boundary-line release criteria for Douglas-fir and ponderosa pine as has been done for several other eastern North American species (Black and Abrams 2005). The Douglas-fir data set from Ponderosa State Park was unusual, however, in that several outliers in percent-growth change values far exceeded the boundary line. No such growth responses were observed in the 25 other sites used to develop the Douglas-fir boundary line, even though these sites were sampled from across the range of the species, including the Pacific Northwest. Furthermore, we found strong agreement between sites in the northwest (Washington) and southwest US (Arizona).

Differences in the Ponderosa State Park site relative to the other Douglas-fir sites included in the ITRDB data set may explain differences in growth responses. First, most of the ITRDB data sets were developed for climate reconstructions, so the samples come from stands on harsh, marginal sites with relatively little competitive pressure. The relatively mesic Ponderosa State Park site may be atypical in terms of edaphic and competitive characteristics that ultimately contribute to vigorous growth responses to disturbance. A second possibility is that the severe suppressions on this site are atypical for Douglas-fir on other sites. The latter seems the most likely explanation considering that all outliers followed a severe suppression and were best classified as growth rebounds rather than true releases. Periods of especially slow growth could contribute to very large increases in percent-growth change once "normal" radial growth has resumed. Regardless of the exact causes of these outliers, this study does provide an example of growth patterns that do not follow those predicted by the boundary line.

\section{CONCLUSIONS}

Our research presents a case study in which we combine several dendroecological techniques for identifying disturbances to forests. By quantifying both release and suppression events, and 
interpreting these in combination with fire scars, traumatic resin rings, and land-use history, we have generated a robust disturbance history of this mixed conifer stand in central Idaho. Boundaryline release criteria are therefore of use in western species. We did, however, detect growth patterns not predicted by the boundary line, and though this appears to be an unusual occurrence, the possibility of atypical sites must be considered before applying boundary-line release criteria. Given that the majority of ITRDB data sets in the western US were sampled for climate studies rather than disturbance studies, particular care should be used when developing boundary lines for western species.

\section{ACKNOWLEDGMENTS}

This research evolved from a project at the $15^{\text {th }}$ Annual North American Dendroecological Fieldweek. Blake Amos, Posy Busby, Jennifer Karps, Kathy Lewis, Nicole Suty and Dave Woodruff all contributed to data collection and analysis at the Dendroecological Fieldweek. We would like to thank the USDA Forest Service Rocky Mountain Research Station in Missoula, MT (particularly Elaine Kennedy Sutherland) for financial support, the staff at the University of Idaho McCall Field Campus for logistical support, Penny Morgan at the University of Idaho for financial and logistical support for post-fieldweek data collection efforts, and Ponderosa State Park and Dennis Coyle for permitting us to collect samples and for providing site history information. Unpublished data from Ponderosa State Park collected by Leon Neuenschwander, University of Idaho (retired) proved useful in this research.

Thank you also to the 2005 Biogeography class at Willamette University who assisted with additional dendroecological lab work, to Jody Lowes who provided additional research assistance, and to several anonymous reviewers.

\section{REFERENCES CITED}

Abrams, M. D., D. A. Orwig, and T. E. Demeo, 1995. Dendroecological analysis of successional dynamics for a presettlement-origin white-pine-mixed-oak forest in the southern Appalachians, USA. Journal of Ecology 83:123-133.
Abrams, M. D., and M. L. Scott, 1989. Disturbance-mediated accelerated succession in two Michigan forest types. Forest Science 35:42-49.

Agee, J. K., 1993. Fire Ecology of the Pacific Northwest Forests. Island Press, Washington D.C.; 493 pp.

Applequist, M. B., 1958. A simple pith locator for use with offcenter increment cores. Journal of Forestry 56:141.

Arno, S. F., and K. M. Sneck, 1977. A Method for Determining Fire History in Coniferous Forests of the Mountain West. USDA Forest Service General Technical Report INT42.

Black, B. A., and M. D. Abrams, 2003. Use of boundary-line growth patterns as a basis for dendroecological release criteria. Ecological Applications 13:1733-1749.

Black, B. A., and M. D. Abrams, 2004. Development and application of boundary-line release criteria. Dendrochronologia 22:31-42.

Black, B. A., and M. D. Abrams, 2005. An evaluation of the boundary-line release criteria for eleven North American tree species. In TRACE-Tree Rings in Archaeology, Climatology and Ecology, Vol. 3, Proceeding of the Dendrosymposium 2004: April 22 $2^{\text {nd }}-24^{\text {th }} 2004$, Birmensdorf, Switzerland, edited by I. Heinrich, and M. Monbaron, pp. 120-126. Jülich: Forschungszentrum, Zentralbibliothek.

Brown, P., and T. Swetnam, 1994. A cross-dated fire history from coast redwood near Redwood National Park, California. Canadian Journal of Forest Research 24:2131.

Colman, S. M., and K. L. Pierce, 1986. The glacial sequence near McCall, Idaho-weathering rinds, soil development, morphology, and other relative-age criteria. Quaternary Research 25:25-42.

Conley, C., 1982. Idaho for the Curious. Backeddy Books, Cambridge, Idaho.

Cook, E. R., and R. L. Holmes, 1983. Program ARSTAN User's Manual. Laboratory of Tree-Ring Research, The University of Arizona, Tucson; $17 \mathrm{pp}$.

Cook, E. R., and K. Peters, 1981. The smoothing spline: a new approach to standardizing forest interior tree-ring width series for dendroclimatic studies. Tree-Ring Bulletin 41:45-53.

Covington, W. W., and M. M. Moore, 1994. Southwestern ponderosa forest structure: Changes since Euro-American settlement. Journal of Forestry 92:39-47.

Craig, W., 2002. Indians in the later Valley County area. Valley County Idaho: Prehistory to 1920, edited by Shelton Woods. Valley County History Project, Roseberry, Idaho.

Crane, M. F., and W. C. Fischer, 1986. Fire Ecology of the Forest Habitat Types of Central Idaho. USDA Forest Service General Technical Report INT-218.

Davis, D. D., M. S. Fromm, and M. D. Davis, 2007. Impact of the hemlock wooly adelgid on radial growth of eastern hemlock in Pennsylvania. Proc. Central Hardwood Forest Conference 15: 157-162. USDA Forest Service e-GTR-SRS-101.

Foster, D. R., 1988. Disturbance history, community organization and vegetation dynamics of the old-growth Pisgah Forest, south-western New Hampshire, USA. Journal of Ecology 76:105-134. 
Grissino-Mayer, H. D., 2001. Evaluating crossdating accuracy: a manual and tutorial for the computer program COFECHA. Tree-Ring Research 57:205-221.

Gruell, G. E., W. C. Schmidt, S. F. Arno, and W. J. Reich, 1982. Seventy Years of Vegetative Change in a Managed Ponderosa Pine Forest in Western Montana: Implications for Resource Management. USDA Forest Service General Technical Report INT-130.

Henry, J. D., and J. M. A. Swan, 1974. Reconstructing forest history from live and dead plant material — an approach to the study of forest succession in southwest New Hampshire. Ecology 55:772-783.

Hessburg, P. F., and J. K. Agee, 2003. An environmental narrative of Inland Northwest US forests, 1800-2000. Forest Ecology and Management 178:23-59.

Hessburg, P. F., J. K. Agee, and J. F. Franklin, 2005. Dry forests and wildland fires of the inland Northwest USA: Contrasting the landscape ecology of the pre-settlement and modern eras. Forest Ecology and Management 211:117-139.

Holmes, R. L., 1983. Program COFECHA User's Manual. Laboratory of Tree-Ring Research, The University of Arizona, Tucson; 8 pp.

Holmes, R. L., and T. W. Swetnam, 1996. Program OUTBREAK User's Manual. Laboratory of Tree-Ring Research, University of Arizona, Tucson; 8 pp.

Hough, A. F., and R. D. Forbes, 1943. The ecology and silvics of forests in the high plateau of Pennsylvania. Ecological Monographs 13:300-320.

Jacoby, G. C., P. R. Sheppard, and K. E. Sieh, 1988. Irregular recurrence of large earthquakes along the San Andreas Fault: Evidence from trees. Science 241:196-199.

Kienast, F., and F. H. Schweingruber, 1986. Dendroecological studies in the Front Range, Colorado, USA. Arctic and Alpine Research 18:277-288.

Lafon, C. W., and J. H. Speer, 2002. Using dendrochronology to identify major ice storm events in oak forests of southwestern Virginia. Climate Research 20:41-54.

Lorimer, C. G., and L. E. Frelich, 1989. A method for estimating canopy disturbance frequency and intensity in dense temperate forests. Canadian Journal of Forest Research 19:651-663.

NOAA (National Oceanic and Atmospheric Administration), 2005. Data archived in the National Climate Data Center, National Oceanic and Atmospheric Administration. Available at [http://www7.ncdc.noaa.gov/CDO/CDODivisionalSelect. jsp] Retrieved May 24, 2007.

NOAA-WRCC (National Oceanic and Atmospheric Administration-Western Regional Climate Center), 2007. Data archived in the Western Regional Climate Center database. Available at [http://www.wrcc.dri.edu/cgi bin/cliMAIN.pl?id5708] Retrieved July 19, 2007.

Nowacki, G. J., and M. D. Abrams, 1997. Radial-growth averaging criteria for reconstructing disturbance histories from presettlement-origin oaks. Ecological Monographs 67: 225-249.

Ogle, K., and V. DuMond, 1997. Historical vegetation on national forest lands in the Intermountain Region. USDA Forest Service, Intermountain Region, 129 pp.
Orwig, D. A., and M. D. Abrams, 1994. Land-use history (1720-1992), composition, and dynamics of oak-pine forests within the Piedmont and Coast Plain of northern Virginia. Canadian Journal of Forest Research 24:1216-1225.

Orwig, D. A., C. V. Cogbill, D. R. Foster, and J. F. O'Keefe, 2001. Variations in old-growth structure and definitions: Forest dynamics on Wachusett Mountain, Massachusetts. Ecological Applications 11:437-452.

Payette, S., L. Filion, and A. Delwaide, 1990. Disturbance regime of a cold temperate forest as deduced from tree-ring patterns: The Tantare Ecological Reserve, Quebec. Canadian Journal of Forest Research 20:1228-1241.

Pierce, J. L., G. A. Meyer, and A. T. Jull, 2004. Fire-induced erosion and millennial-scale climate change in northern ponderosa pine forests. Nature 432:87-90.

Rentch, J., F. Desta, and G. Miller, 2002. Climate, canopy disturbance, and radial growth averaging in a second-growth mixed-oak forest in West Virginia, USA. Canadian Journal of Forest Research 32:915-927.

Rubino, D. L., and B. C. McCarthy, 2004. Comparative analysis of dendroecological methods used to assess disturbance events. Dendrochronologia 21:97-115.

Ruffner, C. M., and M. D. Abrams, 1998. Relating land-use history and climate to the dendroecology of a 326-year-old Quercus prinus talus slope forest. Canadian Journal of Forest Research 28:347-358.

Savage, M., 1991. Structural dynamics of a southwestern pine forest under chronic human influence. Annals of the Association of American Geographers 81:271-289.

Sheppard, P. R., E. M. May, M. H. Ort, K. C. Anderson, and M. D. Elson, 2005. Dendrochronological responses to the 24 October 1992 tornado at Sunset Crater, northern Arizona. Canadian Journal of Forest Research 35:2911-2919.

Sloan, J. P., 1998. Historical density and stand structure in an old-growth forest in the Boise Basin of central Idaho. In Proceeding of the Tall Timbers Fire Ecology Conference. Fire in Ecosystem Management: Shifting the Paradigm from Suppression to Prescription, edited by T. L. Pruden, and L. A. Brennan. Tall Timbers Research Station, Tallahassee, FL. Speer, J. H., T. W. Swetnam, B. E. Wickman, and A. Youngblood, 2001. Changes in Pandora moth outbreak dynamics during the past 622 years. Ecology 82:679-697.

Steele, R., S. F. Arno, and K. Geier-Hayes, 1986. Wildfire patterns change in central Idaho's ponderosa pine-Douglasfir forest. Western Journal of Applied Forestry 1:16-18.

Stephens, S., 1998. Evaluation of the effects of silvicultural and fuels treatments on potential fire behaviour in Sierra Nevada mixed-conifer forests. Forest Ecology and Management 105: 21-35.

Stokes, M. A., and T. L. Smiley, 1996. An Introduction to TreeRing Dating. The University of Arizona Press, Tucson, AZ.

Swetnam, T. W., and J. L. Betancourt, 1990. Fire-southern oscillation relations in the southwestern United States. Science 249:1017-1020.

Swetnam, T. W., M. A. Thompson, and E. K. Sutherland, 1985. Using Dendrochronology to Measure Radial Growth of Defoliated Trees, Agricultural Handbook 639. US Department of Agriculture, Forest Service, Washington DC; 39 pp. 
Taplin, R., and R. Peckham, 1994. Idaho Park and Recreation Board (IDPR) Ponderosa State Park Natural Resource Plan. MeadowHawk Press and Graphics, New Meadows, ID.

USDA-NRCS (United States Department of Agriculture, Natural Resources Conservation Service), 1981. Soil Survey Report of Valley Area, Idaho, Parts of Adams and Valley Counties, Available at: [http://soils.usda.gov/survey/online_surveys/Idaho/ index.html] Retrieved May 25, 2007.

USDA-NRCS (United States Department of Agriculture, Natural Resources Conservation Service), 2007. Soil Survey of Valley Area, Idaho, Parts of Adams and Valley Counties. Map generated on-line at [http://websoilsurvey.nrcs.usda.gov] Retrieved May 25, 2007.

Veblen, T. T., 1986. Treefalls and the coexistence of conifers in subalpine forests of the central Rockies. Ecology 67:644-649.

Veblen, T. T., K. S. Hadley, M. S. Reid, and A. J. Rebertus, 1989. Blowdown and stand development in a Colorado subalpine forest. Canadian Journal of Forest Research 19: $1218-1225$.

Veblen, T. T., K. S. Hadley, and M. S. Reid, 1991a. Disturbance and stand development of a Colorado subalpine forest. Journal of Biogeography 18:707-716.

Veblen, T. T., K. S. Hadley, M. S. Reid, and A. J. Rebertus, 1991b. Methods of detecting past spruce beetle outbreaks in Rocky Mountain subalpine forests. Canadian Journal of Forest Research 21:242-254.

Wood, S. (Editor), 2002. Valley County Idaho: Prehistory to 1920. Valley County History Project, Roseberry, Idaho.

Received 9 August 2007; accepted 25 July 2008

Supplementary Material is available at http://www.treeringsociety.org/TRBTRR/TRBTRR.htm 